\title{
日光国立公園尾瀬地区における利用者数変動要因分析
}

\section{An Analysis of the Fluctuation in the Number of Visitors in the Oze area of Nikko National Park}

\author{
田村 裕希* 青木 陽二** \\ Yuki TAMURA Yoji AOKI
}

\begin{abstract}
This study aims to determine both the factors which account for the fluctuation in the number of visitors and the effect of decentralizing visitors in the Oze area of Nikko National Park. After clarifying the fluctuation in the number of visitors to the Oze area over the past fifteen years, the multiple regression equation was used to examine the fluctuation in the number of visitors in terms of social factors, nature factors and traffic control factors in the Oze area of Gunma prefecture over the last three years. The analysis showed that decentralizing visitors on weekdays had a clear effect on all areas of Oze, and there was an obvious dispersion of visitors away from crowded entrance spots in the area of Oze located in Fukushima prefecture. The analysis showed that decentralizing visitors on weekdays had a clear effect on all areas of Oze, and there was an obvious dispersion of visitors away from crowded entrance spots in the area of Oze located in Fukushima prefecture. The flowering period of the giant skunk cabbage seems an increase in the number of visitors to Hatomachitohge, as do weekend for Ohshimizu. The analysis further showed that controlling the number of private cars and sightseeing buses had some effect on the decentralization of visitors in areas of Gunma prefecture.
\end{abstract}

Keywords: national park, Oze, number of visitors, decentralize visitors, traffic control キーワード：国立公園，尾瀬，利用者数，利用分散化，マイカー規制

\section{1. 研究の背景及び目的}

自然公園においては，すぐれた自然の風景地の保護と利用との バランスを図ることが重要であるため, 自然公園の利用者数を把 握し予測することは公園計画を検討する上で必要不可欠である。 環境省では昭和 25 年から関係機関の協力を得て自然公園の利用 者数を調査しており, 公園別や年次別の利用者数推移によって全 国の自然公園利用動向を把握している ${ }^{1,2)}$ 。

自然公園の中でも, 特に過剩利用が指摘されている日光国立公 園尾瀬地区（以下，尾瀬地区とする）に扔いては，1989 年から 環境省が主要入山口にセンサーを設置し ${ }^{3)}$, 時間別・入山口別利 用者数の集計を開始した ${ }^{4)}$ 。それを基に, 関係機関は尾瀬地区内 の利用バランスを検討し, 予測される利用のピーク日時・場所に 対してマイカー規制等 ${ }^{5}$ を実施している。尾瀬地区でのマイカー 規制は，総利用者数を变化させず，利用者の偏りを分散させる (以下，利用分散化とする) ことを目的の一つとしているため ${ }^{6,7)}$, 特に利用集中が生じやすい 3 シーズン（ミズバショウ期・ニッコ ウキスゲ期・紅葉期）の週末を中心に, 混雑入山口（鳩待峠口・ 沼山峠口）付近において規制がかけられている。しかし，当該規 制による総利用者数への影響や利用分散化効果については, 現在 のところ統計的に明らかにされていないため ${ }^{8)}$, 今後それらを把 握した上で, より有効な利用者数コントロールや利用分散化対策 を講じることが必要である。

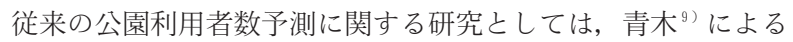
都市公園利用者数の天候・曜日・季節による影響要因分析があり, 利用者数予測のための利用変動式が導き出された。社会要因と自 然要因による影響としては, 藤沼ら ${ }^{10)}$ が奥日光湯元スキー場の利 用者数之駐車場利用台数について分析を行い, 休日等の社会要因 と天候等の自然要因とによって説明可能であることを明らかにし た。これら既往研究を踏まえ, 尾瀬地区の利用者数や利用比率の 変動要因を分析するためには,「自然要因」「社会要因」に加え, 前述の利用分散化を目的の一つとする「マイカー規制による影響
要因（以下，規制要因とする）」を考慮する事が重要である。 以上のことから本研究は, 尾瀬地区全体に打ける過去 15 年間 （1989２003 年）の利用者数の経年变化及び利用分散化効果を把 握した上で, 過去 3 年間（2001 2003 年）の群馬県側を中心之 した日別利用者数及び利用比率变動について「社会要因」「自然 要因」「規制要因」から分析し, 影響要因の抽出之各要因の影響 力を明らかにすることを目的とした。

\section{2. 研究方法}

\section{(1) 使用データ}

利用者数データは全て環境省が所管しているセンサーによる計 測データであり, 過去 15 年間のデータ11) は年別に集計され, 過 去 3 年間のデータ ${ }^{12)}$ は日別に集計されている。計測期間は各年概

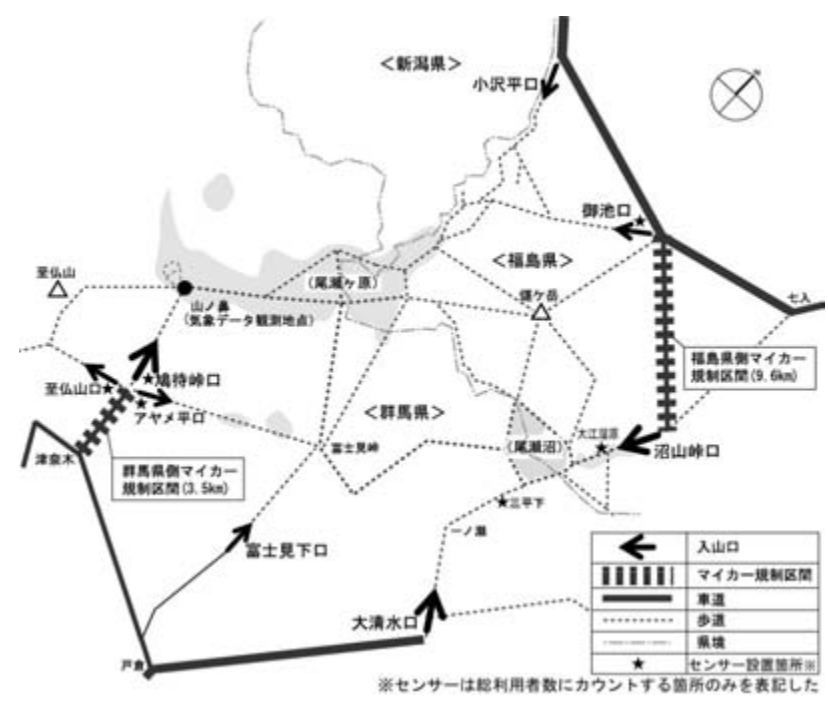

図-1 日光国立公園尾瀬地区概略図

*田村環境計画 **独立行政法人国立環境研究所社会環境システム研究領域 
ね 5 月中旬〜 11 月初旬である。また, 当該デー夕の入山者と下 山者は個別に集計されているが，本研究においては入山者数のみ を利用者数として採用した。要因分析のための気象デー夕は(財) 尾瀬保護財団及び (財) 日本気象協会による「尾瀬山ノ鼻気象観測 表」を使用した。マイカー規制の内容・日程（表一1）は, 毎年 発行のパンフレット ${ }^{13)}$ を参照した。マイカー規制対象区間は群馬 県側の「津奈木一鳩待峠」と福島県側の「御池一沼山峠」の 2 区 間であるが (図一 1), 福島県側は1999年からマイカー通年規制に 切り替えたため, 本研究においては「規制日以外」と「規制対象 日」との規制内容差の大きい群馬県側のみを分析対象とした。

\section{(2) 分析方法}

過去 15 年間の総利用者数, 入山口別利用比率並びに土日利用 比率の経年変化について単回帰分析を行った後, 過去 3 年間の総

表一 1 マイカー規制概要

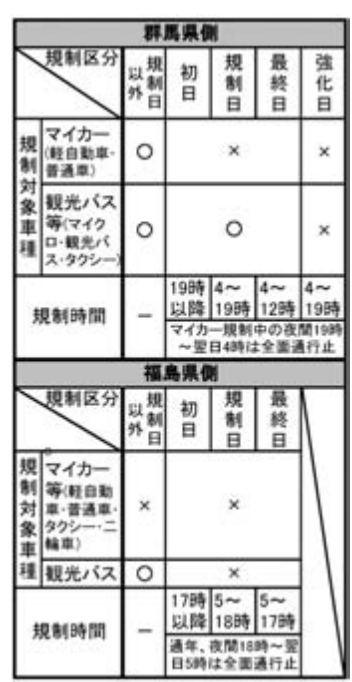

表 -2 重回帰分析の変数概要

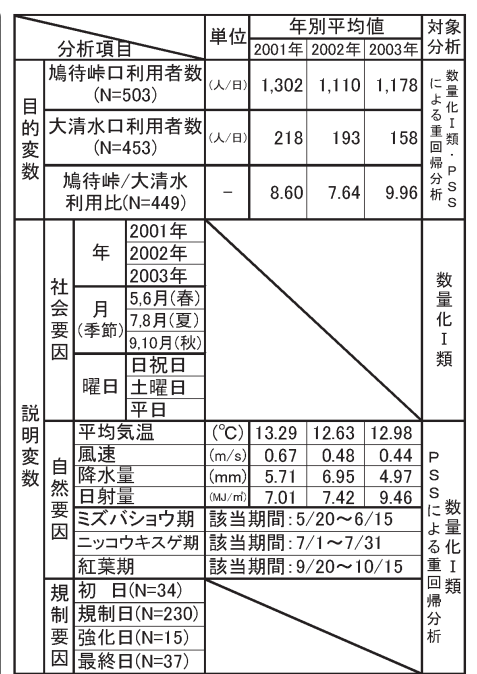

利用者数, 入山口別利用者数並びに土日利用比率について 2 週間 毎の平均值変動の特徵を把握した。また群馬県側のマイカー規制 内容ごとに,「大清水口に対する鳩待峠口利用者数の比率（以下, 鳩待峠／大清水利用比とする)」を整理し，「規制日以外」の鳩待 峠 /大清水利用比との差の検定を行った。

次に，「鳩待峠口利用者数」「大清水口利用者数」並びに「鳩待 峠 /大清水利用比」を目的变数とし「社会要因」を説明变数とし た数量化理論 I 類分析を行った ${ }^{14)}$ 。最後に, 同様の 3 つの目的変 数について「社会要因」「自然要因」「規制要因」を説明变数とし た「PSS（予測平方和）を用いた变数選択を行う重回帰分析 ${ }^{15)}$ （以下，PSSによる重回帰分析とする）」を行い（表一2），影響 要因を確認した。PSSによる重回帰分析は，相関の高い变数の 中で最良の説明変数の組合せを，全ての組合せを計算した上で選 出する分析であるため, 当分析手法として妥当であるといえ, 既 往研究 ${ }^{9,10)}$ を踏まえ変数は表一 2 の通り抽出した ${ }^{16)}$ 。「規制要因」 は前述の通り, 群馬県側のみを分析対象とした。なお, 群馬県側 のマイカー規制は，大きく「マイカー規制日（以下，規制日とす る)」と「規制強化日（以下，強化日とする）」に分けられ，前者 はマイカーのみを規制対象とし, 後者はマイカー及び観光バス等 を規制対象としている。しかし，同じ「規制日」であっても，規 制期間中の「初日」と「最終日」は中日と規制時間が異なるため (表一 1)，本分析ではマイカー規制区分は「初日」「規制日」「強 化日」「最終日」の 4 区分（要因）に捉え直した。分析に当り, 平均気温・風速・降水量・日射量の連続量は数值として用い, そ の他 (不連続量) は夕゙ミー变数として 0,1 の值を用いた。

\section{3 . 分析結果}

（1）過去 15 年間における総利用者数及び利用比率の経年変化 (i) 総利用者数

1989 2003 年に打ける総利用者数の経年变化（表一 3 , 図一 2 ) をみると，1996・1997年がそれ以前より約 10 万人多い。環

表 -3 総利用者数・利用比率の経年変化

\begin{tabular}{|c|c|c|c|c|c|c|c|}
\hline \multirow{2}{*}{$\begin{array}{l}\text { 西暦 } \\
\text { (年) }\end{array}$} & \multirow{2}{*}{$\begin{array}{c}\text { 総利用者 } \\
\text { (人) }\end{array}$} & \multicolumn{5}{|c|}{ 入山口別利用比率(\%) } & \multirow{2}{*}{\begin{tabular}{|c|} 
土日利用 \\
比率 $(\%)$
\end{tabular}} \\
\hline & & 鳵待峠口 & 沼山峠口 & 大清水口 & \begin{tabular}{|l|} 
御池口 \\
\end{tabular} & その他 & \\
\hline 1989 & 467,990 & 44.4 & $\overline{36.3}$ & 13.5 & & 5.8 & 50.8 \\
\hline 1990 & 505,840 & 46.5 & 35.3 & 12.4 & & 5.8 & 51.1 \\
\hline 1991 & 515,090 & 48.4 & 34.0 & 12.1 & & 5.6 & 49.4 \\
\hline 1992 & 539,750 & 49.4 & 32.2 & 12.8 & & 5.6 & 50.3 \\
\hline 1993 & 540,264 & 48.5 & 33.2 & 12.0 & & 6.3 & 50.6 \\
\hline 1994 & 542,058 & 50.6 & 33.9 & 9.9 & & 5.7 & 48.4 \\
\hline 1995 & 534,196 & 55.7 & 28.7 & 9.5 & 3.2 & 2.9 & 52.2 \\
\hline 1996 & 647,523 & 53.8 & 29.8 & 7.7 & 5.7 & 2.9 & 50.1 \\
\hline 1997 & 614,317 & 49.9 & 32.0 & 8.2 & 4.5 & 5.5 & 47.5 \\
\hline 1998 & 455,409 & 48.8 & 33.3 & 3.6 & 6.0 & 8.4 & 48.3 \\
\hline 1999 & 425,807 & 47.0 & 29.7 & 13.0 & 6.9 & 3.4 & 45.4 \\
\hline 2000 & 428,446 & 47.7 & 28.0 & 7.2 & 7.1 & 9.9 & 43.8 \\
\hline 2001 & 448,041 & 49.8 & 26.5 & 7.7 & 5.8 & 10.3 & 47.8 \\
\hline 2002 & 409,942 & 46.5 & 30.2 & 7.3 & 6.9 & 9.1 & 49.3 \\
\hline 2003 & 384,251 & 50.6 & 28.0 & 6.1 & 6.0 & 9.3 & 47.1 \\
\hline 有意検定 & & & ** & * & * & * & ** \\
\hline P值 & & 0.5522 & 0.0002 & 0.0019 & 0.0492 & 0.0335 & 0.0093 \\
\hline 相関係数 & & 0.17 & 0.82 & 0.73 & 0.67 & 0.55 & 0.65 \\
\hline 回帰係数 & & - & -0.54 & -0.49 & 0.31 & 0.30 & -0.33 \\
\hline 定数項 & & - & 1,113 & 991 & -618 & -595 & 699 \\
\hline
\end{tabular}

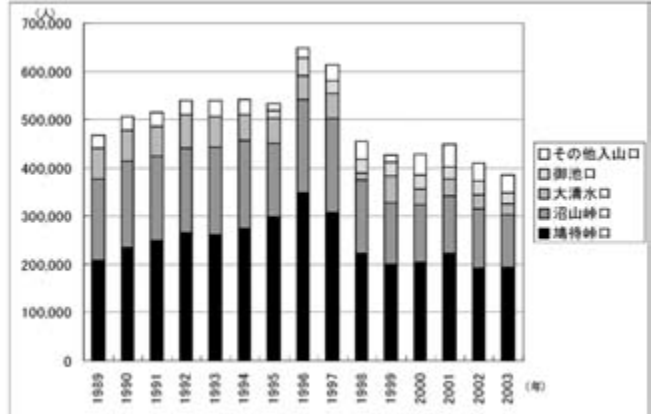

図-2 総利用者数と入山口別利用者数の経年变化
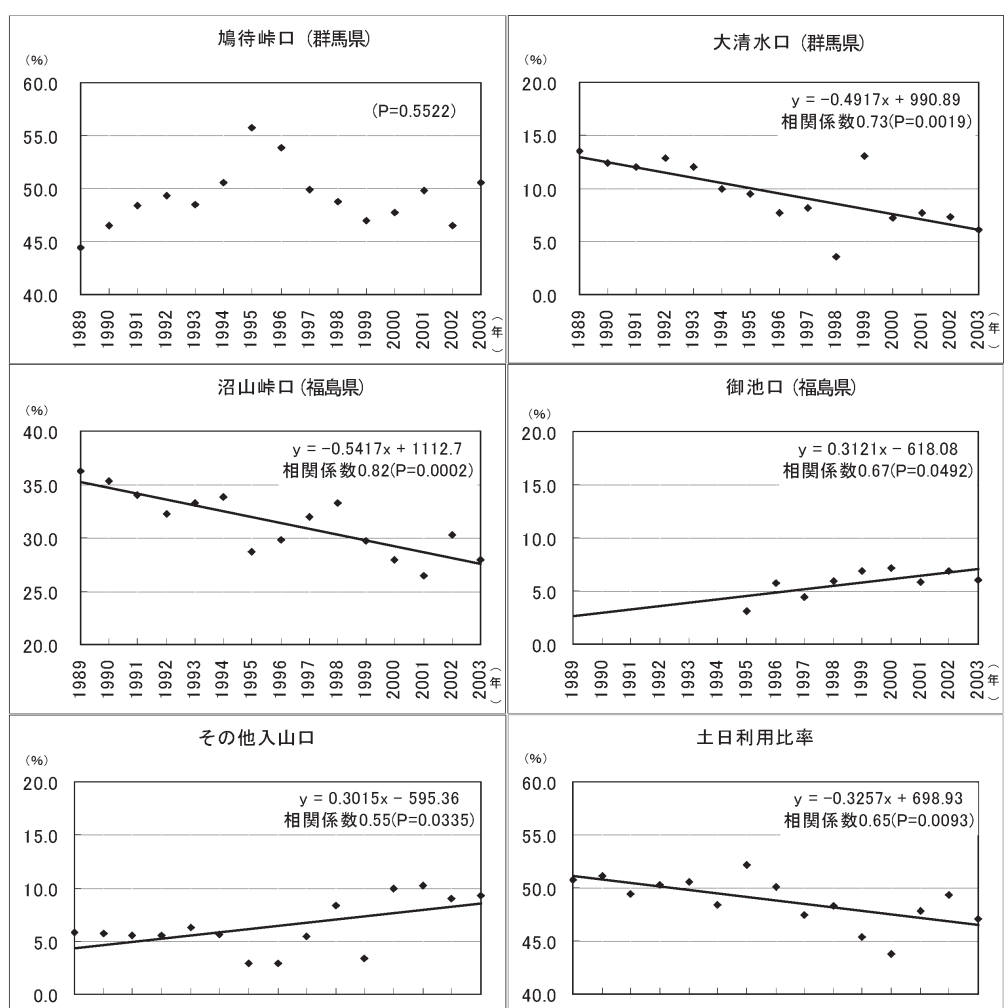

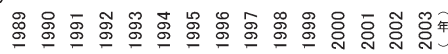

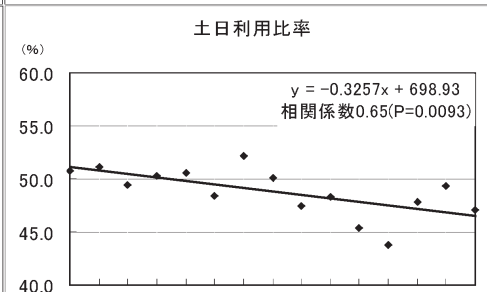

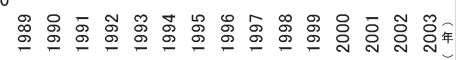

図－３八山口別利用比率と土日利用比率の経年変化 
境省公式発表 ${ }^{11}$ によると, 1996 年は「ミズバショウ開花期の遅 れによる再来訪者の増加，マスコミによる報道増加」が，1997 年は「至仏山東面登山道の再開」が主な原因であると推察されて いる。1998 年以降は 40 万人前後と減少傾向である。

(ii) 入山口別利用比率

入山口別利用比率（表 -3 , 図-3) は, 鳩待峠口が約 5 割, 沼山峠口が約 3 割, 大清水口・御池口・その他入山口 ${ }^{17}$ の合計が 約 2 割を占める。入山口毎に年との相関をみると, 沼山峠口・大 清水口においてそれぞれ $1 \%, 5 \%$ 水準での有意な減少が, 御池 口・その他入山口において $5 \%$ 水準での有意な増加が確認された。 このことから，「福島県側」では沼山峠口（混雑口）から御池 口（非混雑口）への入山口分散化が促進されていると考えられる。 「群馬県側」については鳩待峠口の減少傾向が確認されなかった 点や, 非混雑口である大清水口に減少傾向が確認された点から, 分散化効果が出ているとは言い難い ${ }^{18)}$ 。

\section{（iii）土日利用比率}

土日利用比率は 5 割前後を推移している（表一 3 , 図一 3 )。 年との相関をみると $1 \%$ 水準での有意な減少が確認されこの点か ら尾瀬地区全体として平日利用は促進されていると推測された。

（2）過去 3 年間における利用者数等の変動特徵

（i ）総利用者数及び入山口別利用者数の年間変動

総利用者数は 3 力年共通して ${ }^{19}$ 「 6 月前半 (ミズバショウ期)」 $「 7$ 月後半 (ニッコウキスゲ期)」「10月前半 (紅葉期)」の順に ピークが生じている（図－4）。入山口別17) にみると上記 3 ピー クの順位は異なっており，「鳩待峠口」はミズバショウ期が最も 高く,「沼山峠口」はニッコウキスゲ期が最も高い。理由として は，鳩待峠口は「尾瀬ヶ原 (湿原)」へ，沼山峠口は「尾瀬沼」 へつながる主要な入山口であり季節毎に各空間の魅力・特徵が变 化するためと考えられる。

（ii）土日利用比率の年間変動

土日利用比率（図－5）は 10 月中旬が最も高く約 $65 \%, 8$ 月 中旬は最む低く約 35\%であり, 後者の理由としては当該期間は
夏休み来訪者が多く平日に休暇が取り易いためと考えられる。土 日利用比率は（1）の経年変化分析では約 5 割であったが，通年 变動をみると季節によって大きく变化することが明らかとなった。

（iii）規制要因による利用比率への影響

過去 3 年間の群馬県側におけるマイカー規制の利用分散化に対 する影響を把握するために，「規制日以外」と，「マイカー規制が かけられている日（初日・規制日・強化日・最終日）」の鳩待峠 /大清水利用比についての中央值・平均值・標準偏差を整理した (表一 4)。その結果, 中央值で「強化日」が 5.55 と最も低く, 次いで「最終日」が 5.69 , 「初日」が 6.32 であった。また，「規 制日以外」との差の検定（マン・ホイットニのU 検定）を行っ たところ,「強化日」「最終日」が $1 \%$ 水準, 「初日」が $5 \%$ 水準 での有意差が確認された。「規制日」は $\mathrm{P}$ 值が 0.67 と高く，「規 制日以外」との有意な差は確認されなかった。

このことから，特に「強化日」「最終日」はマイカー規制対象 区間側である鳩待峠口を回避して，規制対象区間外の大清水口を 利用する人が多かったと考えられる。マイカー規制は利用分散化 に対する部分的な効果があり, 利用者数变動に対して少なからず 影響を与えていることが推測された。

（3）過去 3 年間における利用者数及び利用比への影響要因分析

「鳩待峠口利用者数」「大清水口利用者数」並びに「鳩待峠／ 大清水利用比」の日別变動に対して, 社会要因・自然要因・規制 要因の内, 有意に働く要因の抽出とその影響力を分析した。

(i ) 数量化理論 I 類による「社会要因」分析

最初に社会要因である年・月・曜日を説明変数とする数量化理 論 I 類分析を行った結果（表－5），以下の点が明らかとなった。 (1)鳩待峠口利用者数は「月（季節）」「曜日」による影響が大きく， 特に $5 ， 6$ 月（春）と土曜日が大きくプラスに寄与する。

(2)大清水口利用者は「曜日」による影響が最も大きく,「月」の 2 倍以上の影響力を持つ。特に土曜日は大きくプラスに寄与する。 (3)鳩待峠／大清水利用比は「月」による影響が最も大きく, 次い で「曜日」となる。尚, 土日祝日がマイナスに寄与する原因とし

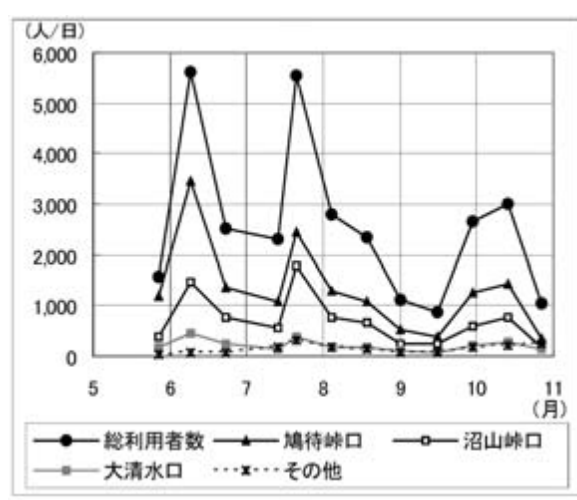

図-4 入山口別利用者数の 2 週間毎の推移 (2001)

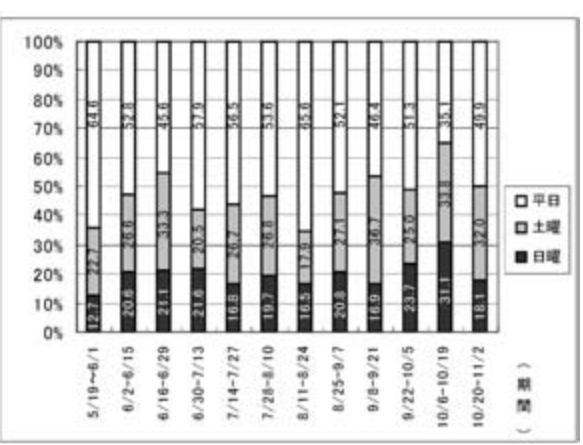

図一 5 土日利用比率の 2 週間毎の推移 (2001)
表一 4 マイカー規制内容ごとの 鳩待峠 /大清水利用比亡検定結果
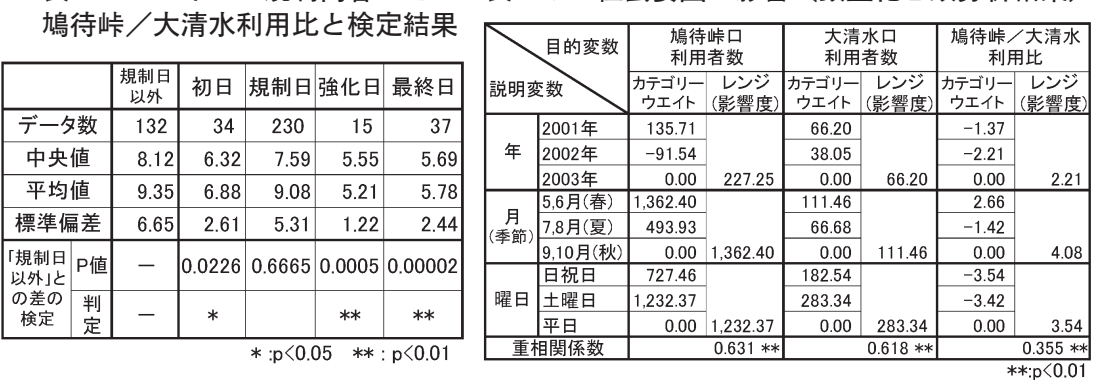

表 -6 社会要因・自然要因・規制要因の影響（PSSによる重回帰分析結果）

\begin{tabular}{|c|c|c|c|c|c|c|c|c|c|c|c|}
\hline \multirow{2}{*}{\multicolumn{3}{|c|}{ 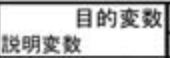 }} & \multicolumn{3}{|c|}{ 斯持的口利用者数 } & \multicolumn{3}{|c|}{ 大清水口刋用者数 } & \multicolumn{3}{|c|}{ 酷待虾／大清永利用比 } \\
\hline & & & 12变数 & 13专数 & $14 \frac{1}{8} \times$ & 13趇傚 & 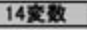 & 15夌砇 & 9夌改 & 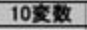 & 11 变数 \\
\hline \multirow{6}{*}{$\begin{array}{l}\text { 社 } \\
\text { 䆖 } \\
\text { 要 }\end{array}$} & & 2001年 & $251.3 * *$ & $243.5 * *$ & $242.4 * *$ & $89.3 * *$ & $88.7 * *$ & $90.4 * *$ & $-1.9 *$ & $-1.9 *$ & $-2.0 * \Rightarrow$ \\
\hline & & 2002年 & & & & $48.8 * *$ & $48.5 * \%$ & $49.4 * *$ & $-2.5 * *$ & $-2.5 * *$ & $-2.4 * *$ \\
\hline & 月 & 5.6月 & $637.5 * *$ & $643.5 * *$ & $641.3 * *$ & $71.1 * *$ & $71.2 * *$ & $73.3 * *$ & & & \\
\hline & (梅筍) & 7.8月 & 145.2 & 173.4 & 170.6 & $67.9 * *$ & $52.4 * *$ & $61.2 * *$ & $-2.5 * *$ & $-2.6 * *$ & $-2.5 * *$ \\
\hline & & 日祝日 & $606.7 * *$ & $597.5 * *$ & $604.0 * *$ & $197.7 * *$ & $196.7 * *$ & $196.3 * *$ & $-3.9 * *$ & $-3.7 * *$ & $-3.8 * *$ \\
\hline & & 土瀷日 & $689.1 * *$ & $692.2 *$ & $693.7 * *$ & $176.0 * *$ & $179.3 *$ & $177.5 * *$ & $-3.8 * *$ & $-3.2 * *$ & $-3.2 *$ \\
\hline \multicolumn{3}{|c|}{ 平均弐期 } & & & & & & -2.4 & & & \\
\hline \multirow{6}{*}{ 目然 } & 盢透 & & $153.8 *$ & $152.6 *$ & $157.0 *$ & & & & & & \\
\hline & \multicolumn{2}{|c|}{ 睛水量 } & & -3.5 & -3.4 & $-0.8 *$ & $-0.8 *$ & -0.7 & & & -0.02 \\
\hline & \multicolumn{2}{|c|}{ 日射量 } & $45.3 * *$ & $42.0 *$ & $41.9 *$ & $5.8 * *$ & $5.7 * *$ & $6.1 * *$ & $-0.2 * *$ & $-0.2 *$ & $-0.2 * *$ \\
\hline & \multirow{2}{*}{\multicolumn{2}{|c|}{$\begin{array}{l}\text { ミスバシ } \\
\text { =ッコウキ }\end{array}$}} & $1.080 .3 * *$ & $1.075 .6 *$ & $1.073 .3 *$ & $65.6 * *$ & $68.4 *$ & $60.2 *$ & $4.1 * *$ & $4.3 * *$ & $4.3 *$ \\
\hline & & & $440.3 * *$ & $433.9 * *$ & $433.4 * *$ & & $34.6 *$ & 33.7 & $2.4 * *$ & $2.7 * *$ & $2.6 * *$ \\
\hline & \multicolumn{2}{|c|}{ 红集䐓 } & $487.0 * *$ & $496.6 * 0$ & $491.3 * *$ & $66.3 * *$ & $67.8 * *$ & $57.4 * *$ & & & \\
\hline 规 & \multirow{2}{*}{\multicolumn{2}{|c|}{ 知制日 }} & & & 67.4 & & & & $-2.9 *$ & $-2.9 *$ & $-2.9 *$ \\
\hline 制 & & & $569.3 * *$ & $564.8 * *$ & $576.3 * *$ & $42.1 * *$ & $39.6 *$ & $41.4 * *$ & & & \\
\hline 要 & \multicolumn{2}{|c|}{ 巽化日 } & $2.268 .5 * *$ & $2.264 .7 *$ & $2.275 .6 * *$ & $510.0 * *$ & $499.0 *$ & $505.1 *$ & & -3.2 & -3.2 \\
\hline \multicolumn{3}{|c|}{ 很終日 } & & & & $-88.4 * *$ & $-86.1 * t$ & $-85.4 * *$ & & & \\
\hline \multirow{2}{*}{\multicolumn{3}{|c|}{$\frac{\text { 定敕项 }}{\text { PSS }}$}} & $-335.0 * *$ & $-296.2 *$ & $-306.4 * *$ & $-51.3 *$ & $-50.3 *$ & -23.1 & $13.0 * *$ & $12.9 * *$ & $13.3 * *$ \\
\hline & & & 0.179 & 0.178 & $0.178 \times 10^{7}$ & 0.657 & 0.653 & $0.653 \times 10^{7}$ & 0.176 & 0.175 & $0.175 \times 10^{3}$ \\
\hline \multicolumn{3}{|c|}{ 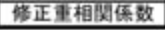 } & 0.853 & 0.853 & 0.853 & 0.800 & 0.801 & 0.801 & 0.408 & 0.413 & 0.413 \\
\hline
\end{tabular}

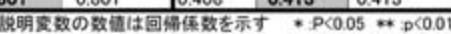


ては，鳩待峠側の土日祝日を中心にかけられているマイカー規制 の影響（規制区間外である大清水口への回避）が考えられる。 (4)「年」の影響は 3 分析とも「月」「曜日」に比べて低いため, 年ごとの利用者数・利用比への影響は比較的小さいといえる。

(ii）PSS による重回帰分析

次に i ）と同様の 3 つの目的变数について「社会要因」「自然 要因」「規制要因」を説明变数とする PSS による重回帰分析を行っ た所 (表一 6 ), 「鳩待峠口利用者数」は 13 变数の時に PSS 值が 最小となり最適な变数が選択され修正重相関係数は 0.857 であっ た。同じく「大清水口利用者数」は 14 変数で修正重相関係数 0.801 , 「鳩待峠 /大清水利用比」は 10 変数で修正重相関係数 0.413 であった。上記 3 結果の修正重相関係数は数量化理論 I 類分 析の重相関係数よりも数值が大きく，説明力は上がったといえる。

当該分析結果から以下の点が明らかとなった。

(1)「鳩待峠口利用者数」はミズバショウ期による影響が極めて強 く, 次いで土曜日であった。一方「大清水口利用者数」は土日祝 日の影響が極めて強く, 次いでミズバショウ期・紅葉期が同程度 の影響力を持つ。尚, 両結果とも規制要因の「強化日」が極端に 大きくプラスに寄与しているのは, 毎年最む混雑が予測される日 （ミズバショウ期の土曜日等）に対して強化日を指定しているこ とが原因であり, そのため当該結果からは規制要因による利用分 散化効果を推測することは出来ない。また「大清水口利用者数」 の「最終日」がマイナスに寄与する点については, 規制解除の 12 時以降に再び鵬待峠側に利用者の流れが戻るためと推測でき るが，他 2 分析では「最終日」は要因として選択されていないた め, 鳩待峠口利用者数に対して当該人数は微量であるといえる。 (2)「鳩待峠／大清水利用比」は，ミズバショウ期・ニッコウキス ゲ期がプラスに寄与することから両シーズンは鳩待峠利用比が増 加し, 反対に規制要因の「初日」と「強化日」がマイナスに寄与 することから両日は大清水利用比が増加するといえる。「強化日」 については（2） iii）の結果と同様, 鳩待峠側のマイカーと観光 バス等の乗り入れが規制されるため分散化効果があると解釈され る。「初日」については規制時間が 19 時以降であることから分散 化の理由は明確ではないが, パンフレット等の表記方法が原因で 利用者に誤って規制時刻が伝達されたと推測される ${ }^{20)}$ 。なお，当 該利用比の修正重相関係数（0.413） は利用者数の結果と比べて 低いため，今後その他影響要因の追及が必要である。

(3)気像による利用者数への影響は, 「日射量」が鳩待峠口・大清 水口ともに $1 \%$ 水準で有意であることから, 尾瀬地区への入山決 定に際しては晴れ間の多さを考慮するといえる。

\section{4. まとめ}

本研究は, 尾瀬地区の利用分散化傾向や利用者数・比率変動に 対する影響要因とその影響力を明らかにするために, 過去 15 年 間（1989～2003 年）の尾瀬地区全体に扔ける利用者数経年变化 や利用分散化効果を把握した上で，過去 3 年間（2001 2003 年） の群馬県側を中心とした利用者数及び利用比率变動要因分析を行っ た。その結果，以下の点が明らかとなった。

(1)尾瀬地区全体の土日利用比率は過去 15 年間において有意に減 少し, 土日利用分散化は促進された。

(2)過去 15 年間で, 福島県側は混雑口（沼山峠口）から非混雑口 (御池口) への利用分散化が促進されたと考えられ, 群馬県側は 混雑口（鳩待峠口）の利用分散化が促進されたとは言い難い。 (3)群馬県側のマイカー規制による利用分散化は「強化日（マイカー 及び観光バス等を規制対象)」には効果が確認され，「規制日（マ イカーのみ規制対象)」には効果が確認されなかった。「初日」と 「最終日」に関しては，明確な解が得られなかった。

(4)過去 3 年間の鳩待峠口利用者数变動はミズバショウ期による影
響が，大清水口利用者数变動は土日祝日の影響が極めて高い。 (5)気象による鳩待峠口・大清水口利用者数への影響は,「日射量」 の影響が最も高く, 尾瀬地区への入山決定に際しては晴れ間の多 さを考慮するといえる。

上記(1)〜 (3)は利用分散化効果，(3)～(5)は影響要因に関する結果 であり，特に(3)からは観光バス規制は分散化効果が高いと考えら れ，今後の利用分散化方策の検討に際して参考になると言える。

本研究の要因分析は主に群馬県側（鳩待峠口・大清水口）を対 象としたが，入山口によって異なった影響要因が作用することが 確認されたため, 今後は福島県側（沼山峠口・御池口・小沢平口 等）や群馬県側の至仏山口・アヤメ平口・富士見下口等について あ分析することが必要である。また，統計資料からの分析だけで なく面接調查等を組み合わせ，利用者意識やマイカー規制回避行 為の実態（回避先やセンサー設置外入山口利用状況等）を把握す ることが重要であり，それによって，より正確な利用者数予測や 利用分散化方策を講じることが可能になるといえる。

謝辞：本研究に使用した貴重なデー夕をご提供戴いた，環境省自然環境 局北関東地区自然保護事務所及び財尾瀬保護財団の方々に，この場を借り て厚く御礼を申し上げます。

\section{補注及び引用文献}

1）環境省自然環境局総務課自然ふれあい推進室 : 2002 年自然公園等利 用者数調について：国立公園 APR.2004：(財国立公園協会，4-7

2) 青木陽二・細野光一 (1997)：自然公園等利用者数の報告担当者調查 の結果について: 第 11 回環境情報科学論文集, 207-212

3 ) センサーは, 1989 年に鳩待峠口・沼山峠口 (大江湿原) ・大清水口 (三平下) に設置され，1995 年に御池口，1997 年に至仏山口，1999 年にアヤメ平口に設置された

4 ) (財) 尾瀬保護財団 : 尾瀬全体の入山者数推移 : < http://www.ozefnd.or.jp/suii.html >, 2003.11.28 更新, 2004.10.25 参照

5 ) マイカー規制の他, 尾瀬ガイダンス, 自然解説活動, ホームページ, パンフレット等で平日利用，入山口の分散化を呼びかけている。

6 ) (財)尾瀬保護財闷・尾瀬入山適正化検討委員会 (1998)：尾瀬入山適正 化検討委員会最終報告

7 ) 古谷勝則・油井正昭 他 (2001)：マイカー規制のもたらす自然公園 利用の諸問題 : 千葉大学園芸学部学術報告第 55 号別刷, $38 \mathrm{pp}$

8 )「尾瀬地区の交通規制効果に関する調查報告書 (2002：財団法人尾瀬 保護財団)」の中で，アンケート調査・面接調査によって交通規制回 避率等が算出されているが，統計的に有意かは分析されていない。

9 ）青木宏一郎 (1984)：公園の利用：地球社, 全 212 頁

10）藤沼康実・青木陽二（1998）：曜日变動之気象条件が奥日光湯元スキー 場の利用に及ぼす影響の分析：ランドスケープ研究 62(2), 181-183

11）過去 15 年間の分析データは「環境省自然環境局北関東地区自然保護 事務所 : 平成元年 15 年度日光国立公園尾瀬地区入山者数について の中から適宜使用した。総利用者数は鳩待峠口・至仏山口・アヤメ平 口・大清水口・沼山峠口・御池口のセンサー計測值にセンサー設置外 入山口利用者数を合算した数值である。センサー設置外入山口利用者 数の推測比率は毎年調整されるが，2001 年以降は富士見下口・小沢 平口等の利用者として全体の $0.9 \%$ に固定されている。

12）過去 3 年間の分析デー夕は，センサー設置外入山口利用者数について 補正されていないため, 総入山者数は, 鳩待峠口・至仏山口・アヤメ 平口・大清水口・沼山峠口・御池口のセンサー計測值の合計を示す。

13）片品村尾瀬交通対策連絡協議会, 福島県尾瀬自動車利用適正化連絡協 議会（2001 2003）: 尾瀬地域の交通対策の打知らせ一自然保護と交 通安全のために一：(財) 尾瀬保護財団, 全 4 頁

14）年・月・曜日の各アイテムから 2003 年・9，10月・平日のカテゴリ を削除し分析した。

15）奥野忠一 (1978) : 予测平方和による变数選択：オペレーションズリ サーチ 23(5), 290-298

16）ミズバショウ期・ニッコウキスゲ期・紅葉期の該当期間は植物図鑑等 を参照し妥当な期間を当てはめた。また,「月」は 2 ヶ月ごとのカテ ゴリーとし, 冬期の長い尾瀬地区では, 5, 6月=春, 7,8 月=夏, 9,10 月二秋といった「季節」の变動要因としても捉えられる。

17）「その他入山口」利用者数は, 過去 15 年間では至仏山口・アヤメ平口・ センサー設置外入山口の利用者合計值とし，過去 3 年間では御池口・ 至仏山口・アヤメ平口の利用者合計值とした。

18）県を越えた混雑口の回避（沼山峠口から大清水口，鳩待峠口から御池 口等) は，車で大きく迂回する必要があるためその確率は低いと考え られるが，今後面接調查等によって回避先を明らかにする必要がある。

19）総利用者数・入山口別利用者数並びに土日利用比率の年間変動特徴は 3 力年ともほぼ共通しているため 2001 年のみ図を掲載した。

20） 2003 年以前のマイカー規制カレンダー（前掲 13)）では，初日と最終 日屯規制日 (中日) と同様に着色されているが, 2004 年のカレンダー では着色を半分にする等，中日と識別しやすいように改善された。 